Journal of Economics and Behavioral Studies (ISSN: 2220-6140)

Vol. 8, No. 4, pp. 123-132, August 2016

\title{
Foreign Exchange Exposure Management Practices by Zimbabwe's Tourism and Hospitality Companies: A Case for the Depreciation of Rand (2014-2016)
}

\author{
Wilford Mawanza \\ Lupane State University, Ascot, Bulawayo, Zimbabwe \\ wilfordma@gmail.com
}

\begin{abstract}
One of the key challenges for tourism and hospitality in the Sub-Sahara Africa (SSA) region is currency behaviours and Exchange rate regime choices. When a company engages in international business foreign currency risk management becomes a crucial part of doing business and the tourism industry of Zimbabwe was not spared on this issue. The objective of this research was to assess the foreign exchange (forex) Exposure Management Practices by Zimbabwe's tourism and hospitality companies. The study was done through a survey on 28 operators in Zimbabwe. A qualitative research approach was adopted in analysis of the data It was found out that the most commonly used ways of reducing the exposure by Zimbabwe's tourism companies were the amicable and mixed-method approaches, of receiving the currency and use it in the country of origin to import materials, matching receipts and payments in foreign currency, risk shifting though it come with low volumes and compromised repeat business. The study recommended that companies and the entire economy must consider invoicing products and services in Rands and even use the rand as a reporting currency. If for example tourism and hospitality players would price regional tourists especially from South Africa and other Rand countries, ignoring the impact of rand depreciation, it would mean that Zimbabwe's tourism and hospitality providers will be in direct competition with the former's own local service providers based on rand priced packages.
\end{abstract}

Keywords: Foreign Exchange, Tourism, Management strategies, depreciation, Rand

\section{Introduction}

The concept of exchange rate regime choice (Jefferis et al., 2013; Sikwila, 2013), and its effects on international business (Kramarenko et al., 2010) has received considerable attention by various scholars, researchers, analysts and practitioners. Kararach et al. (2010) noted that the adoption of the Multi- Currency Regime by Zimbabwe stabilized the macro-economy by containing inflation and allowing the private and public sectors the possibilities of medium to long-term planning. Some degree of business confidence in the economy was restored by the move. Among the risks innate in international business operations, the exchange rate risk represents one of the important considerations for the managers of multinational corporations. Management Foreign exchange exposure has received great attention by companies operating internationally due to a series of recent exchange crises. Significant fortunes have been made and lost due to the unusual behaviour of the foreign exchange rates and markets (Soenen, 1979). Due to a prolonged era of economic decline and hyperinflation during the period 2007 through to 2008, Zimbabwe abandoned its own currency, the Zimbabwe dollar in 2009 after years of record high levels of inflation. As a mitigatory measure, the government switched on to a new foreign exchange rate regime or multicurrency system, a variation of dollarization in order to map a way forward on economic growth. This exchange rate regime choice which was somewhat informal and partial variation of dollarization saw the country accepting the use of multiple currencies which among the dominant ones included the United States dollar, the British pound, South African rand, the Botswana pula and the Euro and this policy was made to effect 30 January 2009 during the country's fiscal policy presentation. It has been using the US dollar as its functional currency ever since, the South African rand is also widely accepted though the US dollar has mainly been adopted as the reporting currency by many entities including the government, hence the country described as a dollarized economy. Given this kind of a set up, the United States of American Dollar (USD), become the most pronounced currency amongst a basket of various other currencies supporting the regime. 
Following that move, Zimbabwe's tourism industry as one of the drivers of economic growth had been making its way through towards sustainable revival as business prospects appeared flowery from all facets, that is local, regional and international. Responding to a recovering and stable environment, statistics from the tourism authority of the country indicates that arrivals to the country were on the upward trend after some years of ailing in the low. Statistics released by the Zimbabwe Tourism Authority (ZTA) (2010), showed that the country recorded a 2.8 per cent increase in tourist arrivals in the first half of 2009 as the industry was approaching towards its former status of one of the prime tourist destinations in Africa. The table 1 below shows statistics of the Zimbabwe-South Africa tourism and trading history.

Table 1: Zimbabwe's Tourism and Trading Data with SA

\begin{tabular}{ll}
\hline ITEM & STATISTICS/Estimate \\
\hline SA arrivals to Zimbabwe 2013 Q1 & 37294 \\
Growth rate in SA arrivals to Zimbabwe & $6 \%$ \\
Imports from SA & US $\$ 7.15$ billion \\
Exports to SA & US $\$ 3.25$ billion \\
\hline
\end{tabular}

Source: http://victoriafalls24.com/, Zim Statitics (2013)

Mzembi (2016) in www.fin24.com noted that Sub-Sahara Africa (SSA) region's tourism business is mainly affected by the behaviour of currencies against major currencies. He commended that the loss in the value of the rand has have negative effects on the on the country's hospitality and tourism industry following the over reliance on the US dollar. This made Zimbabwe to be viewed as an expensive destination for regional visitors and South Africans being the main trading partners and consequentially this resulted in a decrease in SA's contribution to regional business in Zimbabwe. Therefore, against this back ground, when a business is involved in international business and finance, foreign exchange rate risk becomes a fundamental cause for concern especially when cash flows and values of sales oscillates in response to currency fluctuations.

Main Objective and significance of the study: The main objective of this study is to assess the impact of the rand depreciation and Zimbabwe's multicurrency regime choice on tourism industry. The study was motivated by the fact that South African is one of the big source markets for the industry in the country and the regional business component was the most affected. The research seeks to find out the main areas of the tourism business that were most affected, and how companies managed to deal with problem at hand. The significance of the study is three fold: First for practising managers, it will act as a practical tool in understanding risks inherent in international business and in developing strategies that minimizes these risks while not harming the other business operations. Secondly recommendations made will also guide policy makers on the consequences of certain exchange regime choice. Lastly, little research has been made on effects of exchange regime choices on Zimbabwe's tourism sector; hence the study is expected to contribute to the existing body of knowledge on foreign exchange exposures and the management strategies for organisation engaging in international business activities

\section{Literature Review}

According to Solakoglu (2005) Foreign exchange rate risk represents one of the important considerations for the financial and risk managers of multinational companies' from the various risks common in international business. Foreign exchange exposure management is a very important in the context of international trade and investments; and research of the subject has been done much. To have a better review of literature, the concept of foreign exchange rate will be presented first followed by exposure management strategies and empirical studies conducted before.

What is foreign exchange risk? Foreign exchange exposure can be defined as the amounts of currencies which represent the sensitivity of the future real local currency (market) value of any financial or physical asset to random variations, in future domestic purchasing powers of these foreign currencies, at some given future date (Adler and Dumas, 1984). Foreign exchange risk is where values from the statement of profit or loss and the statement of financial position in a business are affected when there is movement in foreign exchange rates. According to Soenen (1979), the assets and liabilities of multinational companies, by 
definition, are held, and their income stream achieved, in a number of currencies. Movements in the exchange rates of foreign currencies may negatively affect the reported earnings or profits and the nominal net worth of the company. When a company decides to go international, no matter what the business is, foreign currency risk management becomes a vital part of the daily business life. According to Backlund (2011) translation and transaction exposures are the most common currency risks that companies are faced. These risks are seen as both opportunities and threats, and companies have various ways of dealing with these exposures, usually following the company's own risk management policy. Exchange rate movements have been a big concern for analyst, managers, investors and shareholders since the breakdown of Bretton Woods's system in the 1970s (Solakoglu, 2005). Alssayah and Krishnamurti (2013) indicated that companies are exposed to the risk of changing exchange rates through many channels. For instance, if a company depends on international sales, it becomes exposed to the risk of foreign exchange rate fluctuations. For example if the company has receivables denominated in Rands and the Rand depreciates relative to the U.S. dollar, the dollar-value of the Rand receivables is altered and so the firm's profits and its net worth changes. Jong et al. (2006) indicated that it is not necessarily only those firms engaged in exporting or importing activities or are classified as multinational corporations that are exposed to changing exchange rates. They commented that local players that might not have any international earnings are not involved in cross-border sales may also be affected by changing exchange rates, possibly indirectly through their competition with other importing companies. The exposure comes through three main types as discussed below.

Types of Foreign Exchange Exposure: Shapiro (2013) explained the three main types of exchange rate risk in international finance, i.e., translation, transaction and economic exposure. These are explained below.

a) Translation/Accounting Exposure: Accounting exposure divides the balances sheet's assets and liabilities into those accounts that will be affected by exchange rate changes and those that will not. This is intrinsic when a multinational company is consolidating its financial statements from subsidiaries and affiliate or activities from one currency to the reporting currency. During the consolidation financial statements by MNCs, the translation could be done either using the end-of-the-period exchange rate or using an average exchange rate of the period, depending on the accounting standards and regulations affecting the parent company. According to Papaioannou (2006), given that statements of profit or loss are usually translated at the average exchange rate over the period, statement of financial position exposures of foreign subsidiaries are often translated at the prevailing current exchange rate at the time of consolidation. Accounting exposure for a foreign subsidiary is usually measured by the exposure of net assets (assets less liabilities) to potential exchange rate moves. From a statement of profit or loss point of view, the translation exposure can be noticed on the item "foreign exchange loss/profit".

b) Transaction Exposure: This results from a firm taking on "fixed" cash flow foreign currency denominated contractual agreements. This exposure has a time frame equal to the horizon of the already established contractual agreements, and the cash flows only include those determined in the contracts. The most typical issues in this case is the accounts receivables and payables that is affected by changes in foreign exchange rates, but also investments and loans denominated in foreign currency (Eriksen and Wedøe, 2010).

c) Economic Exposure: Economic exposure reflects the risk to the firm's present value of future operating cash flows from exchange rate movements. Basically, it concerns the effect of exchange rate changes on revenues (domestic sales and exports) and operating expenses (cost of domestic inputs and imports). Economic risk is usually applied to the present value of future cash flow operations of a firm's parent company and foreign subsidiaries.

Managing Foreign Exchange Exposure: In order to develop a strategy for managing currency risk it is important for companies to first identify and measure the various types of currency exposure. There are two broad ways through which foreign Exchange rate exposure can be managed, namely, Contractual (External) hedge methods and Operational (Internal) hedging methods. These depend on the level of development of financial markets. Abor (2005) carried out a study on the foreign exchange risk management on Ghanaian companies and their results indicated that almost $50 \%$ of the companies do not have any well-functioning risk-management system. Foreign exchange exposure was mainly managed by adjusting prices to reflect changes in import prices resulting from currency fluctuation, and also by buying and saving foreign currency in advance. They commented that the main problems faced by firms are the frequent appreciation of foreign currencies against the local currency and the difficulty in retaining local customers because of the high prices 
of imported inputs, which tend to affect the prices of their final products sold locally. For example, If the company owns receivables denominated in Rands and the Rand depreciates relative to the U.S. dollar, the dollar-value of the Rand receivables is altered and so the firm's profits and its net worth changes.

Using a Contractual Hedge to Deal with Exposures: According to EDC (2012) this involves buying foreign exchange hedging instruments that are typically sold by banks and foreign exchange brokers. The ones most commonly used are: foreign exchange forward contracts, currency options and swaps. For the purpose of this study, contractual hedges maybe ignored in the analysis since they mainly deal with derivative instruments from which the level of development of financial market is not yet conducive for the trading of those.

Internal/operational Hedging techniques: Internal hedging techniques are cheaper than external techniques and should therefore be considered first. Internal hedging techniques include leading and lagging, invoicing in home currency, matching and multilateral netting (BPP ACCA P4, 2015)

a) Hedging via Lead or Lag: To lead is accelerate the collection of a receipt or payment of an obligation in order to take advantage of a favourable movement in exchange, or in anticipation of a pending devaluation of depreciation of a currency. For instance foreign trade payables can be settled earlier (leading) if there is anticipation of devaluation or depreciation of local currency.

b) Invoicing in home currency /risk shifting: Wherever possible, have the overseas subsidiaries bill their customers in another strong currency instead of local currencies. This is seen as an especially good strategy in countries where the prospect for local currencies is depreciation against the dollar. It puts all the currency risk on the customer (Soenen, 1979). One way of avoiding transaction risk is for an exporter to invoice overseas customers in its own domestic currency, or for an importer to arrange with its overseas supplier to be invoiced in its home currency.

$\checkmark$ If a Zimbabwean tourism services provider is able to quote and invoice an overseas customer in US dollars, then the transaction risk is transferred to that customer.

$\checkmark$ If a Zimbabwean tourism services (importer) is able to arrange with its overseas supplier to be invoiced in US dollars then the transaction risk is transferred to that supplier.

$\checkmark$ Although either the exporter or the importer avoids transaction risk, the other party to the transaction will bear the full risk. Who ultimately bears the risk may depend on bargaining strength or the exporter's competitive position (it is unlikely to insist on payment in its own currency if it faces strong competition).

$\checkmark$ An alternative method of achieving the same result is to negotiate contracts expressed in the foreign currency but at a pre-determined fixed rate of exchange

Bergendahl \& Sjögren (2011) found out that Swedish firms use currency as a competitive advantage offering suppliers and customers to invoice in "home" currency, and the introduction of the Euro has not affected their operations. Types of products (standardized or customised) affect the hedging procedures.

c) Matching receipts and payments: A company can reduce or eliminate its transaction exposure by matching receipts and payments. Wherever possible a company that expects to make payments and have receipts in the same foreign currency should plan to offset its payments against its receipts in that currency. The process of matching is made simpler by having foreign currency accounts with a bank. This method is rarely used due to the uncertainty of timing of the cash flows. The inflow and the outflow must occur at exactly the same time to provide a 'perfect' hedge (CPA Australia www.cpaaustralia.com.au 2009).

d) Do nothing follow the prevailing exchange rates: With this strategy you act on the day you want to buy or sell your foreign currency. While simple, this approach means you will not know how much local currency you will need to pay or receive for your foreign currency until the day in question. This can be a high-risk strategy as the exchange rate may have moved significantly since you agreed the price with your customer/supplier. If rates have moved the wrong way, your profit will be reduced accordingly.

Mathur and Knowles (1985) conducted a survey among 300 major U.S. multinationals to examine their foreign exchange risk management practices. Two-thirds of the respondents, generally the larger ones, had formal written policies for managing foreign exchange risks. Their results showed that approximately onethird of a firm's exposure to foreign exchange risks was covered through hedging operations and the vast majority of firms were using techniques such as intra-corporate netting of corporate transactions, and 
speeding up or delaying remittances, accounts receivable, and accounts payable. Minimal utilization of interest arbitraging indicated that very few firms were actively involved in speculating in foreign exchange markets.

\section{Methodology}

The research was conducted through a survey on 28 tourism and hospitality entities operating in Zimbabwe to examine they deal with foreign exchange risk management.

Data collection: A "mix and match" approach was adopted for research instruments. One of the procedures that was take by the research was to approach managers and Accountants of tourism players during the annual event of the tourism fair, Sanganai/Hlanganani, and interviews on the effects of the depreciating rand to their operations and how they deal with the vice. This data collection instruments is flexible and it gave the researcher the opportunity to probe some of these data obtained. Interviewees will given the chance to build on their responses and give more explanation when the need arise in the collection process. Above all a questionnaire was used to collect data that was later used in the SPSS software. The questionnaires were given company financial managers, General Managers or other senior managers, all of whom were expected to have a thorough understanding of their firm's exposure to exchange rate risk in question.

Questionnaire design: The questionnaire was included a covering note with permission to do research, ethical issues and contact detail for the researcher. The type of questions includes both closed-ended and open-ended questions. Open-ended questionnaire allows respondents to give as much information as possible at their own liberty. Closed-ended questions would be answered by simply checking a box or circling the proper response from a set provided by the researcher (Fowler, 1993). The aim of the questionnaire was to establish the effects of the depreciation of the rand to tourism business and then to assess the measures taken by companies in trying to reduce the effects.

Sampling design: Convenience sampling was employed as it was a cost-effective and efficient means of gathering data given that the population of the study was very large and dispersed across a large geographic area. A total of 40 questionnaires sent out, and 28 were returned back to give a response rate of 70 percent. The data from questionnaire were captured into an SPSS application and analysed through descriptive statistics.

Reliability: In order for the study questionnaire to measure what it is supposed to measure, pilot testing was done before the study questionnaire is used in actual data collection. A sample questionnaire was given to 5 respondents at Sanganai Tourism Fair. These partook in the study after which it was checked for completeness, ambiguity and language. Necessary adjustments were made before the actual data collection exercise. In the pilot study, respondents were asked to indicate questions that they found ambiguous, those questions that they are uncomfortable with and to make any other comments that could improve the questionnaire.

\section{Data analysis and Results}

Following is a presentation and analysis of data.

Analysis of the companies' business models: The survey first dwell much on the main business line of each company survey within the tourism and hospitality range, that is, whether, hotel, resorting, transport and tour, fast food, recreation etc. The results of the analysis are shown in table 1 below.

Table 2: Main Business Line

\begin{tabular}{lll}
\hline & Frequency & Percentage \\
\hline Catering & 2 & 7.1 \\
\hline
\end{tabular}




\begin{tabular}{lll}
\hline Hotel \& Leisure & 22 & 78.6 \\
Tour Operator & 3 & 10.7 \\
Tour, Hotel \& Leisure & 1 & 3.6 \\
Total & 28 & 100.0 \\
\hline
\end{tabular}

From a wide spectrum of the Tourism and Hospitality activities in the country, the table above shows that most respondents (78.6 percent) were in the hotel and leisure business. This category of leisure included a wide range of activities like fishing, cruising, wildlife and gaming. Resorts and monuments were also included under the 'hotel and leisure' band. Having looked at the tourism activity by company, the research focused on the reporting currency used by each entity during the period under study and hence the effect of depreciating rand on business operations. Table 2 below shows a cross tabulation of the reporting currency used by a company and the effect of the depreciating rand to regional tourism. Results showed that about 93 percent of the entities surveyed used the United States dollar as the reporting and functional currency, which become a good case to focus on given the problem in question. One participant indicated that they used the South African Rand and other was using both USD and Rand concurrently. The reasons given by those reporting in Rands were that their head office or parent companies were from the Rand area. A follow up question was made in order to identify the various areas that have been affected by the vice. The results at shown in table 2 below

Table 3: Companies' Reporting Currency * Effect of Rand depreciation

\begin{tabular}{lllll}
\hline & & $\begin{array}{l}\text { Effect of Rand depreciation on } \\
\text { Business Operations for the Past } \\
\text { year }\end{array}$ & & \\
& & Adversely & No effect at all & Total \\
\hline Companies' & Reporting South African Rand & 1 & 0 & 1 \\
Currency & US Dollar & 22 & 4 & 26 \\
& US Dollar/Rand & 1 & 0 & 1 \\
Total & & 24 & 4 & 28 \\
\hline
\end{tabular}

For the cross tabulation above, it shows that 86 percent (24 companies) indicated that they were adversely affected by the depreciation of Rand against the USD. 4 entities indicated that there was no effect at all and they were all using the USD as their reporting and transacting currency.

Regional Business: The goal of this write up was to assess the impact of Zimbabwe's multicurrency regime choice on tourism following the depreciation of the Rand against the US Dollar and assess the foreign exchange exposure/risk management strategies by tourism companies in Zimbabwe following the depreciation of the Rand against the USD. Therefore it was imperative for the researcher to look at the contribution of regional business from SA to the overall business portfolio of an entity. The information on that is presented in figure 1 below.

Figure 1: Proportion of Regional Business 


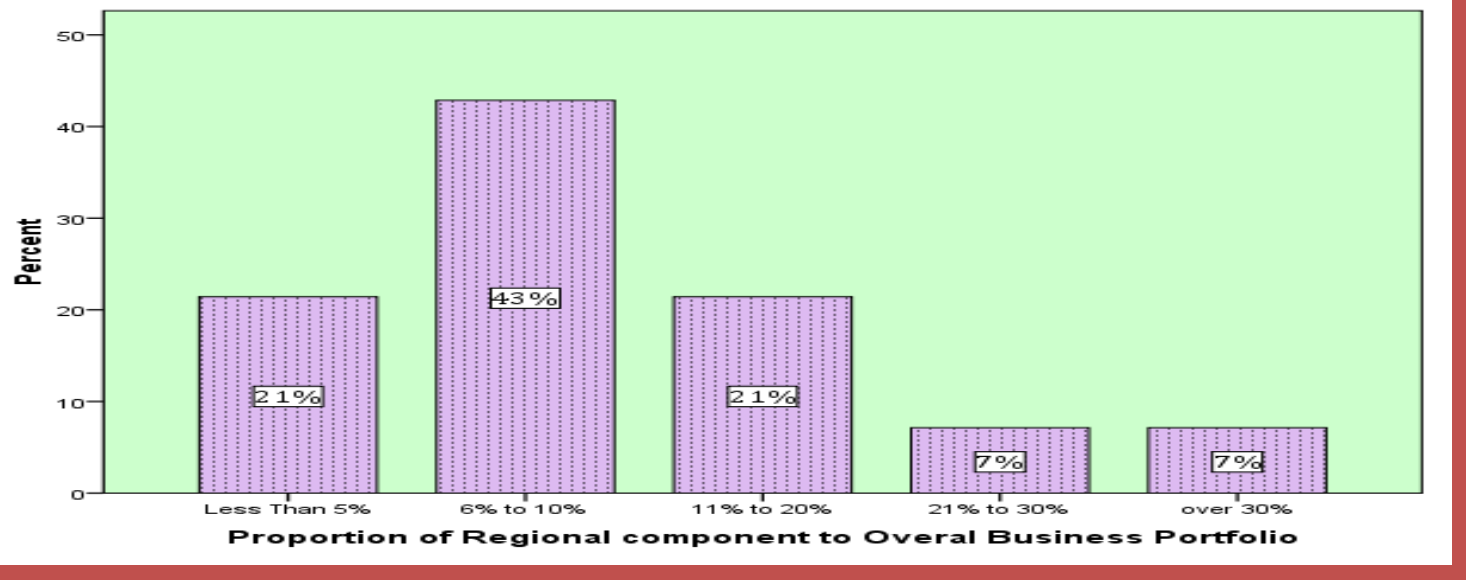

Indeed the regional tourists are contributing a significant share of the tourism revenue. 14 percent of the entities indicated that the Rand area contribute more than $20 \%$ of their total revenue, while the majority ( 85 percent) indicated that regional business constitute more than between $6 \%$ to $20 \%$. This state of affairs made it further possible to evaluate the effects of the depreciating Rand and how further the entities managed to deal with the vice.

Effects of the depreciation: Given the fact that the Rand area contributes a significant proportion of the tourism and hospitality business in Zimbabwe, certain variables were identified as the most affected following the depreciation of the Rand against the dollar. As indicated in table 3, 82 percent were mainly exposed to transaction risk through receipts from debtors, 71 percent of the respondents' coined volumes and occupancy as the most affected variable and 50 percent indicated the growth of foreign exchange loss. The other areas indicated as most affected were: pricing policies and payments to creditors as shown in table 4 below.

Table 4: Areas Affected

\begin{tabular}{llll}
\hline & & \multicolumn{2}{l}{ Responses } \\
& & N & Percent \\
\hline \multirow{3}{*}{ Areas $^{\mathrm{a}}{ }^{\mathrm{a}}$} & Receipts from Debtors & 23 & $82 \%$ \\
& Pricing policies & 11 & $39 \%$ \\
& Revenues & 11 & $39 \%$ \\
& Volumes and Occupancy & 20 & $71 \%$ \\
& Payments to Creditors & 4 & $14 \%$ \\
& Foreign Exchange Loss & 14 & $50 \%$ \\
Total & & & $100.0 \%$ \\
\hline
\end{tabular}

Foreign exchange loss was one of the main worry for player in the industry and the following is a snapshot of the range in Dollar value terms of average monthly loss for each entity. Table 5 below shows the cross tabulation of foreign exchange loss and proportion of regional business 
Table 5: Proportion of Regional component to Overall Business

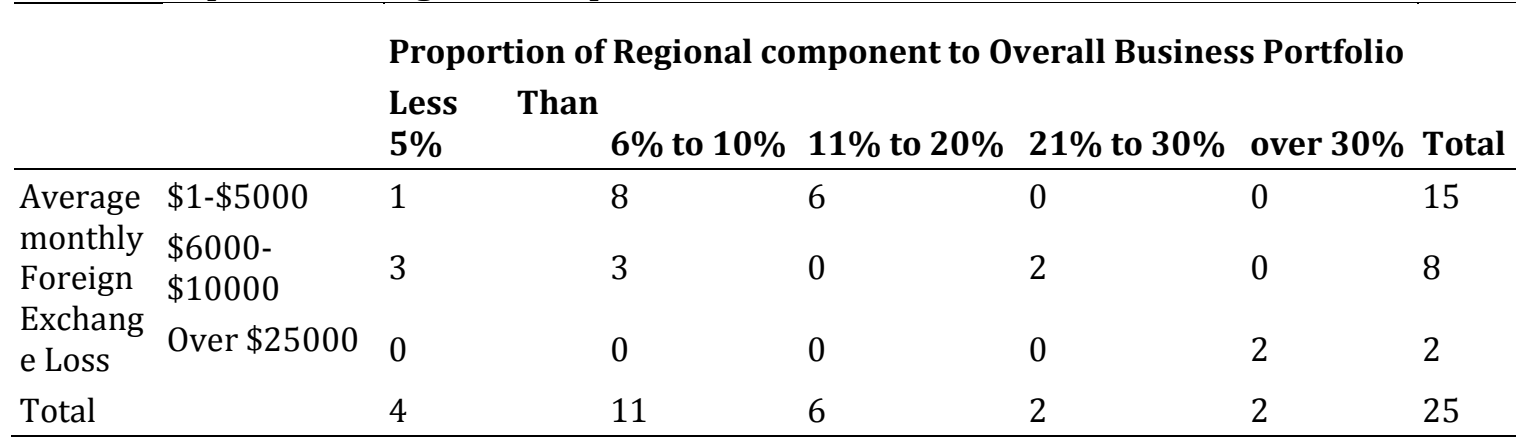

The research showed that translation risk affected companies as evidenced by an 89 percent response, having this line item on their profit and loss statements. From the data in table 4 above, there is evidence of the effect of the depreciation on regional business. The higher the regional component on the business portfolio, the higher will be the exchange loss. However 36 percent indicated that they are experiencing exchange losses of more than $\$ 6000$ and the balance are in the range of $\$ 1$ to $\$ 5000$. This is pure evidence that companies are exposed to foreign exchange rate risk, both transaction and translation. As commented by Abor (2005) that the main problems the firms face are the frequent appreciation or depreciation of foreign currencies against the local currency and the difficulty in retaining local customers because of the high prices of imported inputs, which tend to affect the prices of their final products sold locally. Companies indicated the following as measures put in place to retain regional customers as they are an important component for growth of the sector.

- Customer loyalty has been difficult to maintain as regional business has taken a knock and there is not enough local and international business to replace the regional component, thus we are considering going back to quoting SA clients in Rand and absorb the exchange losses.

- Intensified marketing strategies through South African office targeting mainly the South African Market as it is one of the regional contributor to our volumes and occupancies

- Maintaining standard rate of exchange that result exchange rate loss in hope of tapping into regional market in the long run.

- Offer discounts and credit Facilities

- Having a 2-tier pricing system

The question is how these companies are managing the exposure and at the same time managing repeat business from the regional component as it is crucial for the growth of the sector. The following table shows the various strategies used by companies in mitigating the vice.

Table 6: Rand Exposure Management Strategies

\begin{tabular}{lll}
\hline & Frequency & Valid Percent \\
\hline Use the Rands to make purchases in SA & 21 & 75 \\
Pricing in USD shifting the exposure to clients & 15 & 54 \\
Matching Rand payments with Rand Receipts & 6 & 21 \\
Do nothing & 1 & 4 \\
Reduction of prices and rates & 11 & 39 \\
\hline
\end{tabular}

From table 5 above, a majority of respondents ( 75 percent) used a very wise strategy which balances the two spectrums of retained business and exposure reduction. With this approach, they indicated that there was a deliberate move to buy products from SA to reduce the rand exposure and cut costs as SA products would land cheaper compared to procuring locally, while in other instances local suppliers were selling goods from SA, thus eliminating the foreign exchange risk and the middlemen at the same time. This was achieved by entities doing a two tier pricing strategy so that from the Rand guest's perspective, the local product becomes affordable than if the dollar rate was used. Thus 39 percent resorted to relationship building strategies of 
quoting in US dollars but at a lower rate to make the products and service affordable. This middle of the road approached will be favourable both to the company and to the customer. Half of the respondents however pointed out that they manage exposure through risk shifting though it comes with some fall outs.

Discussion: The results of the study showed that most of the tourism companies use the USD as reporting currency and by so doing have been so prone to the adverse effects of the depreciating rand against the USD. The effects were mainly extensive due to the fact that the regional component of the tourism contributes on average a minimum of $6 \%$ to the overall business volumes. It was further explored that the depreciation impact manifested itself through transaction exposure on areas like receipts from receivables and volumes or occupancies even though translation risk was realised through marginal increases in exchange loss. The study indicated that the maximum possible loss that could be incurred was over US $\$ 25000$. The effect were also realised through a decrease in retained business and loyalty of regional tourists. When the volatility started in 2013, some companies indicated that they made deliberate move to stop quoting rates in Rand and quote the regional customers in USD, however at discounted rates compared to the international clients. This however has seen the decline in the S A business and other Rand based countries. However as mentioned by (Soenen, 1979) this is seen as an especially good strategy in countries where the prospect for local currencies is depreciation against the dollar. It puts all the currency risk on the customer. In this case the local reporting and transaction currency was appreciating against the foreign currency which would make the destination less competitive. Tourism is a service industry based on destination accessibility and affordability together with perception, loyalty and proper promotional activity hence risk shifting won't be ideal for Zimbabwe given the economic status of the country. As noted by Minister of Tourism in an article by Smith (2016), the depreciation of the rand has certainly impacted Zimbabwe's tourism industry, which often prefers to be US dollar based making it more expensive for South Africans a big source market and the net impact has been a reduction of SA as a source market in the SADC region. A few companies however indicated that they have established an office in the Rand area with a foreign bank account that can be used to match Rand receipts and Rand payments without converting to USD. This will reduce the exchange loss item of the profit and loss statement while at the same time not jeopardising credit relations with customers. Having realised the effects of the vice, players in the industry resorted to some natural ways of reducing foreign exchange exposure. Among them was to receive the weak rand and use it to buy equipment and raw materials from South Africa, matching Rand receipts and payments especially by those who have a head office in the rand area.

\section{Conclusion}

It was noted from the research that the tourism industry in Zimbabwe was hard hit by the depreciation of the rand against the dollar given the nature of its regime choice. This was evidenced the growth in foreign exchange loss visa-vie the regional business component from the Rand area. The most affected areas being receipts for the rand debtors, Revenues, volumes and occupancies. Companies however were caught in a fix by the nature of the forex regime in the country in which it tends to be difficult to constitute and device measures to reduce foreign exchange exposure. However the most commonly used ways of reducing the exposure by Zimbabwe's tourism companies were the amicable and mixed-method approaches, of receiving the currency and use it in the country of origin to import materials, matching receipts and payments in foreign currency, risk shifting though it come with low volumes and compromised repeat business.

Recommendations: Against the conclusion the following recommendations have been suggested: It is recommended that companies and players in the sector use an integrative approach in managing risks inherent in business operations by aiming at integrating the company with its clients for continuity and repeat business. Whilst they are managing their bottom line, a stakeholder's approach of doing business should always be considered. It is also recommended that companies and the entire economy consider invoicing products and services in Rands and even use the rand as a reposting currency If for instance, tourism and hospitality players would price regional tourists especially from South Africa and other Rand countries, ignoring the impact of rand depreciation, it would mean that Zimbabwe's tourism and hospitality providers will be in direct competition with the former's own local service providers based on rand priced packages. That monetary authority together with concerned authorities considers formally adopting the rand as the main currency so as to enable smooth trade with neighbouring countries. The formal dollarization will bring in more advantages and stability to various sectors of the economy. That the government reduce taxes 
and tariffs on regional business so as to expand the sector and make the destination attractive to visitors at the same time improving the easy of doing business. This survey was narrowed towards a particular sector; there severity of the depreciation could have been measured throughout the entire economy. There future studies should focus on the effects of the depreciation on the entire economy and feasibility of joining the rand union as a foreign exchange regime choice.

\section{References}

Abor, J. (2005). Managing foreign exchange risk among Ghanaian firms. The Journal of Risk Finance, 6(4), 306-318.

Adler, M. \& Dumas, B. (1984). Exposure to currency risk: definition and measurement. Financial management, 2, 41-50.

Alssayah, A. \& Krishnamurti, C. (2013). Theoretical framework of foreign exchange exposure, competition and the market value of domestic corporations. International Journal of Economics and Finance, 5(2), 1.

Backlund, H. (2011). Currency Risks and Currency Risk Management.

Bergendahl, G. \& Sjögren, S. (2011). The Effects of Changed Policies and Regimes within European Financial Markets on MNCs' Foreign Exchange Exposure Management.

BPP Learning Media Customer Services. (2015). ACCA P4 - Advanced Financial Management - Study Text

CPA Australia Ltd. (2009). A guide to managing foreign exchange risk accessed at site www.cpaaustralia.com.au

Eriksen, K. \& Wedøe, O. (2010). Foreign exchange risk management: How are the largest non-financial companies in Norway managing their foreign exchange rate exposure?http://www.sciencedirect.com/science/article/pii/0281752785900131

Export Development Canada, EDC. (2010). Managing Foreign Exchange Risk White paper, Accessed at: http://www.edc.ca/EN/Knowledge-Centre/Economic-Analysis-and

Research/Documents/managing-foreign-exchange-risk-guide.pdf

Fowler, F. (1993). Survey Research Methods, Sage, Newbury Park, CA. http://victoriafalls24.com/blog/2013/07/02/south-african-tourist-arrivals-to- zimbabweincrease-in-2013/ South African tourist arrivals to Zimbabwe increase in 2013,

Jefferis, K., Chigumira, G. \& Chipumho, E. (2013). A Review of Zimbabwe's Optimum Future Currency Regime, Zimbabwe Economic Policy Analysis and Research Unit. (ZEPARU)

Jong, A., Ligterink, J. \& Macrae, V. (2006). A firm-specific analysis of the exchange-rate exposure of Dutch firms. Journal of International Financial Management \& Accounting, 17(1).

Kararach, G., Kadenge, P. \& Guvheya, G. (2010). Currency reforms in Zimbabwe: An analysis of possible currency regimes. The African Capacity Building Foundation. OCCASIONAL PAPER No. 10, 2010

Kramarenko, V., Engstrom, L., Verdier, G., Fernandez, G., Oppers, S. E., Hughes, R. \& Coats, W. (2010). Zimbabwe: Challenges and policy options after hyperinflation. African Department Paper, 10(03).

Mathur, I. \& Knowles, L. L. (1985). Foreign exchange risk management strategies of U.S. multinationals. Scandinavian Journal of Management Studies, 2(1), 41-59, ISSN 0281-7527,

Mzembi, W. (2016). SA tourists skip Zim due to weak rand - minister, Fin24 Apr 07 2016 http://www.fin24.com/Companies/TravelAndLeisure/sa-tourists-skip-zim-due-to- weakrand-minister-20160407

Papaioannou, M. G. (2006). Exchange rate risk measurement and management: Issues and approaches for firms. South-Eastern Europe Journal of Economics, 4(2).

Shapiro, A. C. (2013). Multinational Financial Management, 10th Ed (Hoboken, New Jersey: John Wiley \& Sons, Inc.)

Sikwila, M. N. (2013). Dollarization and the Zimbabwe's Economy. Journal of Economics and Behavioural Studies, 5(6), 398-405.

Smith, C. (2016). SA tourists skip Zim due to weak rand - minister, retrieved from http://www.fin24.com/Companies/TravelAndLeisure/sa-tourists-skip-zim-due-to-weak-rand minister-20160407.

Soenen, L. A. (1979). Foreign exchange exposure management. Management International Review, 3, 31-38.

Solakoglu, M. N. (2005). Exchange rate exposure and firm-specific factors: Evidence from Turkey. Journal of Economic and Social Research, 7(2), 35-46.

The Financial Gazette. (2014). Rand decline affects Zim tourism, accessed at http://www.financialgazette.co.zw/rand-decline-affects-zim-tourism/. 